\title{
A Very Small Glacier on Mt. Chokai, Japan, 1972-1981
}

\author{
Iwao Tsuchiy *
}

\begin{abstract}
With reference to the IASH's classification in World Glacier Inventory (UNESCO/IASH, 1970) and the revised classification by Miiller et al. (1977), the author has proposed a type of mountain glacier, the sub-alpine niche glacier formed by abnormally heavy snowfalls and the drifted snow, but not including any kind of avalanche, and named it the "Mount Chokai type glacier" (Tsuchira, 1978 b). During the period 1972-1981, yearly field surveys on the "Kaigata Glacieret," one of these types of glaciers, were carried out and the results showed several peculiar features of a very small glacier.

Kaigata Glacieret was formed at about $1400 \mathrm{~m}$ a.s.l., some $2000 \mathrm{~m}$ below the so called climatic snowline, and covered about $0.04 \mathrm{~km}^{2}$ during a one-year period of development, and then diminished to form tiny ice patches during the course of a few years. The estimated maximum snow depth at the site of this glacier at the end of a snowfall season was about $45 \mathrm{~m}$ or more. The ablation rate is very high and the observed maximum rate during a warm rainstorm was $1.4 \mathrm{~cm} / \mathrm{h}$. The rate of glacier ice development was very fast. The density of the remnant snowpack on this glacier continued to increase almost up to the stage of glacier ice after only one ablation season.

The flow rate of the Kaigata Glacieret showed some variation. In the ablation years following accumulation, such as 1975 and 1979, the flow was more rapid. Similar features are recognized on other smaller perennial snow patches (including ice bodies) in the Japanese snowy mountains, but there had been no observational evidences on the flow before 1975 .

A comparison with similar small glaciers such as the Whakapapanui in New Zealand showed some common features, such as the site of formation being far below the climatic snowline, westerly prevailing winds in the snowfall season, leeward slope fronts at low latitudes, snowdrifts as the main nourishment sources, and large interannual fluctuations.
\end{abstract}

\section{Introduction}

There are many perennial snow patches in the snowy mountains of northern Honshu and Hokkaido (Tsuchiya, 1974; Higuchi, 1979). Recent studies of these areas showed several old ice masses, rapid firnification, and glacier ice development (WAKAнAMA et al., 1969; Tsuchiya, 1977). The density of glacier ice becomes more than 0.83 when the interconnecting air passages between the grains (ice crystals) are sealed off. This density level is observed in several snow patches in Japanese mountains. In this paper, density is taken as the main criterion for the definition of ice, firn and snow. Until the time the author discovered glacier ice structure and glacial flow in one of these snow patches on Mt. Chokai and recognized it as a small glacier
(Tsuchiya, 1978a), many geographers and earth scientists in Japan had been of the opinion that no glaciers exist in this region at present and that the many cirque topographies resulted from the Quaternary glaciation.

With reference to the IASH's classification in World Glacier Inventory (UNESCO/IASH, 1970) and revised by MüLLER et al. (1977), the author has proposed a type of mountain glacier, namely a type of niche glacier, the sub-alpine niche glacier formed by abnormally heavy snowfall and drifted snow, but not including any kind of accumulation by avalanche, and named it the "Mount Chokai type glacier" (Tsuchiya, 1978b). IASH's definitions of "mountain glacier" and "glacieret and snowfield" are "any shape, sometimes similar to a valley glacier, but much smaller; frequently located in cirque or niche." and "a glacieret

\footnotetext{
* National Institute for Environmental Studies. Yatabe-machi, Tsukuba-gun, Ibaraki-ken 305, Japan.
} 
is a small ice mass of indefinite shape in hollows, river beds and on protected slopes developed from snow drifting, avalanching and/or especially heavy accumlation in certain years; usually no marked flow pattern is visible and, therefore, no clear distinction from snowfield is possible. Exists for at least two consecutive summers." Several Mount Chokai type glaciers can be seen in the leeward sub-alpine environments on the southern slope of Mt. Chokai. The lowest glacier, "Kaigata Glacieret" was formed at about $1400 \mathrm{~m}$ a.s.l., some $2000 \mathrm{~m}$ below the so called climatic snowline. This glacier covers about $0.04 \mathrm{~km}^{2}$ during a one year period of development. The site of the glacier has a mean monthly temperature higher than $17^{\circ} \mathrm{C}$ in the warmest month.

Kaigata Glacieret is a typical Mount Chokai type glacier. During 1974 and 1975, Kaigata Glacieret developed into a thick ice mass in a leeward shallow hollow or niche topography facing the northwest winter monsoon wind, after extremely heavy snowfalls and snowdrifts which resulted in an accumulation depth of more than $30 \mathrm{~m}$. There are several niche glaciers similar to Kaigata Glacieret on Mt. Chokai, the largest one being about $0.1 \mathrm{~km}^{2}$.

Though Kaigata Glacieret is very small, it may be considered a kind of mountain glacier, which is nourished in a rather warm environment. This facilitates the study of the snow cover and temperature in the transformation from snow cover to glacier. Extinction and rebirth of this glacier are resulted from the slight change of climate. There were several occasions in which the transient glacial phenomena were due to large interannual net accumulation variabilities. The results of this study indicate that several critical factors are involved in the formation of a glacier. In a previous work (Tsuchiy A, 1977, 1978a), the author reported the interannual fluctuation of Kaigata Glacieret during the period from 1972 to 1975. Additional observations with regard to glacial flow, shape and ablation process were carried out from 1976 to 1981.

In this paper, the compiled data set based on the field surveys from 1972 to 1981 were used to make clear the features of Kaigata Glacieret. Clarification has been made of the critical factors involved in the transition of a snow cover into a glacier on the basis of a comparison of the features of Kaigata Glacieret with reference to the other small glaciers. These similar size glaciers are those situating under the same latitude and similar climatic conditions in New Zealand. And perennial snow patches in other regions of Japan are referred to as well.

Another problem to be considered is characteristic of natural vegetations such as snow patch communities resulting from interactions between ice bodies formed at the site of a plentiful precipitation and a warm environment in summer which enables trees and surrounding biota to grow.

\section{A review of Japanese perennial snow patches}

The Japan Sea coastal zones in northern Honshu and Hokkaido are regions which incur the heaviest snowfall in the world. Winter snowfalls account for 40 percent or more of all precipitation in the mountainous regions, with annual precipitation reaching several thousand millimeters. The summer temperature in Japan, except the extremely northern districts, is almost the same as that in humid tropical countries, and heavy rainfalls are caused by activities of front and cyclone in the early summer rainy period. Frequent tropical and extratropical cyclones are made more severe by the mountainous regions in Japan (e.g. Fukui, 1977). Even in the alpine and sub-alpine zones, the temperature is high and the amount of rainfall is rather considerable in summer, causing many deep snowpacks formed from heavy snowfall in winter to vanish. Although most perennial snowpacks are reduced to very small patches, a considerable number of small perennial snow and ice patches persists in the snowy mountains of Japan (Tsuchiy A, 1974).

Assuming that the definition of the climatic snowline is the lower limit of the altitude where air temperature in the warmest month does not exceed $0^{\circ} \mathrm{C}$, the snowline in Hokkaido and in northern Honshu are about $3,500 \mathrm{~m}$ and $4,000 \mathrm{~m}$, respectively. Thus, it can be said that there is no mountain higher than the climatic snowline in Japan. Accordingly it is hard to find mountain glaciers which exceed 
$1 \mathrm{~km}^{2}$ in their areas under the climate of Japan, although there have been additional accumulations from local and accidental avalanches or exceptional heavy snowfalls. As the result, there are many perennial snow patches of $0.01-0.2 \mathrm{~km}^{2}$ in leeward hollows. But there are not so many places with snow or ice masses which meet the definition of a snow field or glacieret according to the glacier classification by UNESCO/IASH (1970), since this definition is based on at least two consecutive summers.

Perennial snow patches in Japan are usually classified into two groups with respect to the accumulation process: a snowdrift type and a snow avalanche mixed type. In determining whether these perennial snow patches grow into small glaciers or not, attention should first be directed to the snowdrift type involving no accidental snow avalanche since in this case the critical conditions for glacier transformation are more easily understood than those of the snow avalanche mixed type.

There are several hundred perennial snow patches at least the size of $0.01 \mathrm{~km}^{2}$ above in Japan, and the total area may come to $10 \mathrm{~km}^{2}$ or more in one year with heavy snowfall. Several field reports indicate that most of these snow patches are of the snow avalanche mixed type, the snowdrift types being fewer and limited to northern Japan.

Structural characteristics of snow patches of the drift type is much similar to those of the deep accumulated snow. Rapid firnification of the deposited snow has been reported in those snow patches, but investigations on glacial flow or deformation of them have not been made except for Kaigata Glacieret (Tsuchiy A, 1974, 1976; Higuchi, 1979; WaKahama and Yamada, 1979). Figure 1 shows the distribution of mountains where snow fields and glacierets are clearly and/or probably existing, along with the details of distribution of the snowdrift type perennial snow patches on Mt. Chokai. In this figure, No. 1 is the largest snow field or glacieret in this region, and No. 3 is Kaigata Glacieret, which is located at the lowest altitude of all the glacierets in Japan.

There are snow avalanche mixed type perennial snow patches in Japan, which bury the deep valleys of the sub-alpine zones and alpine

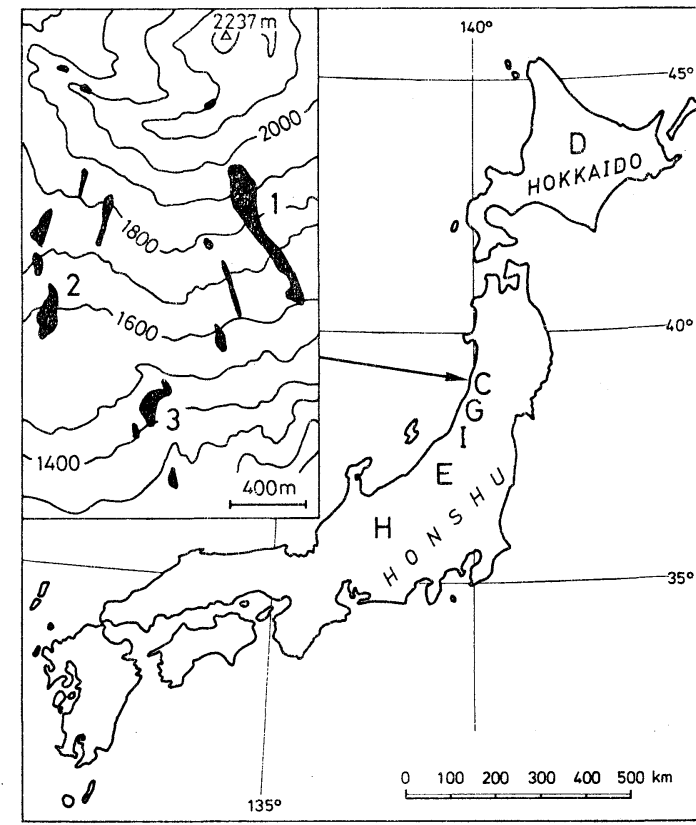

Figure 1. Mountains and the existing many perennial snow patches in Japan and the details on Mt. Chokai in 1974.

(D: Mt.Daisetsu C: Mt.Chokai G: Mt. Gassan I: Mt. Iide E: Echigo Range H: Hida Range 1: Omata 2: Shinji-yuki 3 : Kaigata 1,2 and 3 : may be niche glacier)

zones in the higher mountains in central and northern Japan. The reason for their topographical limitations is not well understood. The larger snow patches frequently reach a length of about $2 \mathrm{~km}$. Glaciological field surveys on them are rare, even though possible glacial phenomena may be in progress.

One important feature of Japanese perennial snow patches is the extremely large amount of the summer ablation. Particularly on torrential rainstorm days, it is impossible to measure a snow stake as it is washed away or falls down. For example, the remnant snow of a firn stage of $58.5 \mathrm{~cm}$ depth was ablated completely in forty hours during a two day warm $\left(16^{\circ} \mathrm{C}\right)$ rainstorm in August 1979 on Kaigata Glacieret. An exact measurement of the amount of one summer ablation has not yet been made, but a vertical borehole of about $30 \mathrm{~m}$ in Mt. Gassan on May 17, 1973 (Tsuchiy A, 1974) can provide a good index for this. The remnant snowpack at this borehole site diminished almost completely by the beginning 
(a)

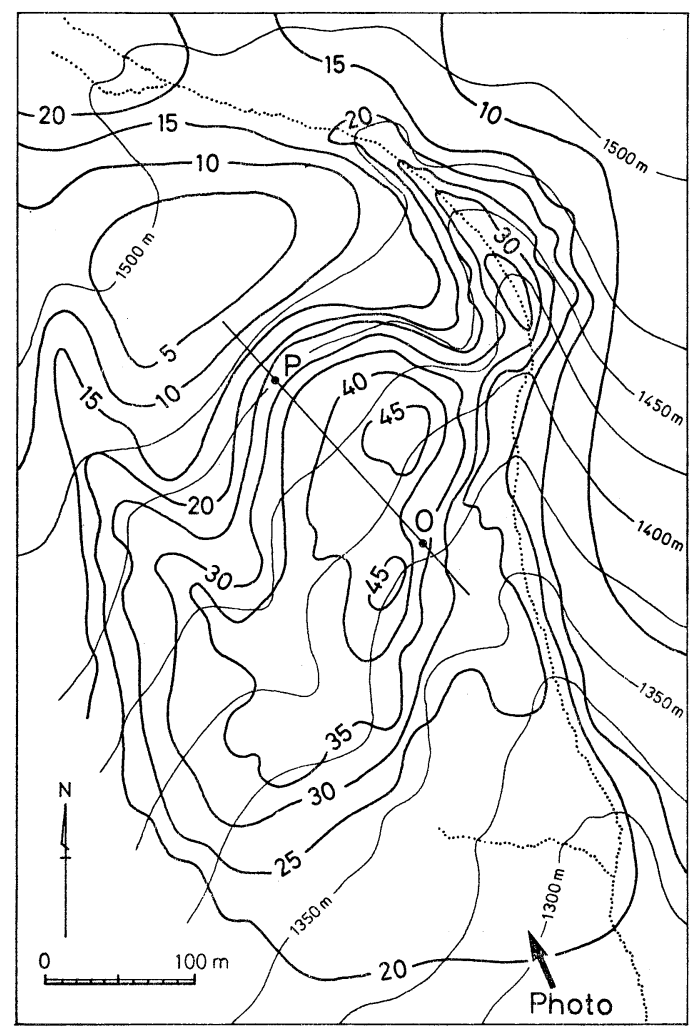

(b)

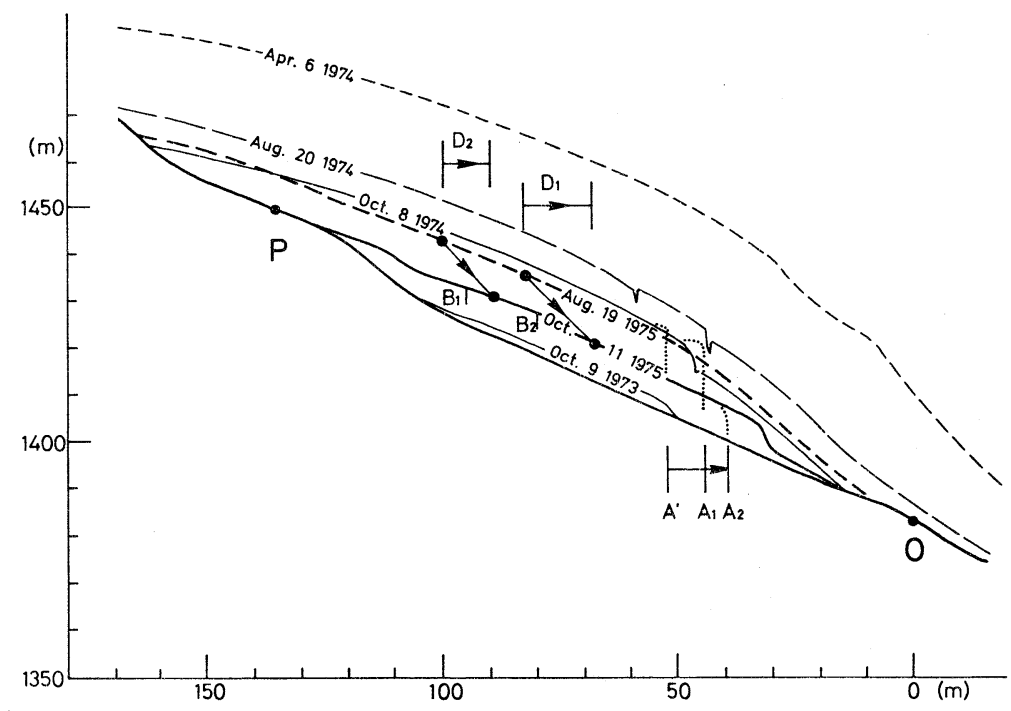

Figure 2. (a) Snow depth (m) on April 6,1974 on the southern slope of Mt. Chokai based on the airborne photogrammetric snow depth contour map. (Based on Tsuchiya, 1978a)

(b) A profile of Kaigata Glacieret at the same place. $\left(\mathrm{D}_{1}\right.$, $D_{2}$, and $A^{\prime}-A_{2}$ are glacier flows from August 19 to October 11 , and $B_{1}$ and $B_{2}$ are ice temperature observation points on October 11, 1975). (Based on Tsuchiya, 1978a) 
of the autumn snowfall season in that year. About $30 \mathrm{~m}$ snow depth is considered to be the annual ablation amount at this site at a mean annual air temperature of $3^{\circ} \mathrm{C}$, which should be the same for Mt. Chokai. For Mt. Daisetsu, Hokkaido, where the northern latitude is higher, this amount was estimated to be about $20 \mathrm{~m}$ (WaKahama and Yamada, 1979). The mean annual temperature at this site was about $-3^{\circ} \mathrm{C}$.

\section{Extraordinarily deep snowpack on Mt. Chokai}

According to many textbooks on Japanese climate (e.g. Fukur et al., 1977), the heavy snowfall occurring along the Japan Sea coast during the winter is usually associated with the prevailing northwest winter monsoon air currents originating over extremely cold Siberia. These cold air currents come under the warm moist Japan Sea air and pass over the mountains near the coast, causing cumulus clouds to develop which results in stronger wind currents with greater precipitation as they ascend over the mountain tops.

The summit of Mt. Chokai $(2,237 \mathrm{~m})$ is situated about $15 \mathrm{~km}$ from the Japan Sea coast: thus the above mechanism very effectively brings about many heavy snowfall days. The resulting snow accumulation is far more than $5 \mathrm{~m}$ in depth on the leeward slope with additional snowdrifts. Snow sampling was technically difficult for a deep snow cover at this depth. Recently it has become possible to construct an approximate annual maximum snow depth map based on airborne photogrammetric surveys, by subtracting the contour at the end of the preceding summer from the contour at the end of a snowfall season. Figure 2-a shows a part of the snow cover depth map of Mt. Chokai on April 6, 1974 based on this technique (Tsuchiy A, 1978a). On this map, a site with a depth of $45 \mathrm{~m}$ at Kaigata Glacieret can be seen. This is a very deep snow, but it does not occur every year and should be regarded as a remarkable heavy snowfall in northern Japan during the 1973/74 winter. There were no such heavy snowfalls from $1974 / 75$ to $1980 / 81$ according to Table 2 . The snowfall for the 1978/79 winter was about a half of that in 1973/74 winter and the max- imum depth of about $20 \mathrm{~m}$ can be estimated from the summer ablation measurements and snow cover photographs from different years.

\section{Rapid firnification and glacier ice development}

In October 1973, the density of the remnant snowpack on Mt. Chokai was that of an iced firn (density: about 0.7-0.83), a stage between firn and glacier ice (the glacier ice stage having a density of more than 0.83 ) at the end of the first ablation season. In the following year, the two-year-old snowpack developed completely into ice under the first-year snowpack, which was confirmed by a survey in a tunnel formed in Kaigata Glacieret (Tsuchiy A, 1977). Table 1 shows the results of the several density measurements during 1977-1981. The density of a two-year-old layer was the same as ice, and the first year layer was either iced firn or glacier ice. This densification of a

Table 1. Density measurements of one-year (surface zone) layers and two-year (lower zone) layer on Kaigata Glacieret.

\begin{tabular}{c|l|c}
\hline \multicolumn{1}{c|}{ Date } & Measuring position & Density \\
\hline $\begin{array}{l}\text { Sept. 23 } \\
1978\end{array}$ & downstream & 0.68 \\
Aug. 19 & $\begin{array}{l}\text { upstream } \\
\text { snout }\end{array}$ & 0.69 \\
1979 & downstream & 0.87 \\
Aug. 13 & downstream & 0.73 \\
1980 & snout & 0.73 \\
Sept. 14 & 0.91 \\
1980 & $\begin{array}{l}\text { downstream } \\
\text { downstream } \\
\text { Sept. } 15\end{array}$ & 0.70 \\
1981 & (two-year) & 0.90 \\
\hline
\end{tabular}

snowpack is considered very rapid when compared to that of the high mountains in the middle latitudes or the high polar areas where long years are required for the transformation of snow to glacier ice.

The main process in the transformation of snow into glacier ice consists of 1) the compaction by heavy and deep snow accumulation and 2) the refreezing of the melting water from the surface snow coming into contact with a layer 
below $0^{\circ} \mathrm{C}$ within the snow cover. The first process occurs in very cold regions such as high polar areas and high mountains in the mid-latitude. In these areas, many years are required for tens of meters of snow to accumulate due to the relatively small amount of snowfall. But the depth of the snow cover on Kaigata Glacieret exceeded $45 \mathrm{~m}$ toward the end of the snowfall season in 1974. The density of snow on Kaigata Glacieret was very high compared with that of the high latitude cold areas because of the somewhat lower latitude of $39^{\circ}$, the altitude being $1400 \mathrm{~m}$, and the nearby warm sea.

The second process involving melting-refreezing is the major process in the sub-polar zone with a short warm summer period and higher mountains with alternative warm fine days and snowy cold days in summer. The meltingrefreezing processes commonly occur on moun tain glaciers in the European Alps and coastal mountains of Alaska. Sometimes both processes take place on the same mountains.

Whether the melting-refreezing process does occur or not on Mt. Chokai has not been completely confirmed, but the possibility was suggested by the existence of ice temperature as low as -2 or $-3^{\circ} \mathrm{C}$ in two-year-old ice near the surface zone of Kaigata Glacieret before the arrival of the first frost day in autumn of 1975 (Tsuchiy A, 1978a, b). The temperature of ordinary snowpacks in Japanese mountains during the melting season is usually $0^{\circ} \mathrm{C}$ and not below $0^{\circ} \mathrm{C}$, but NaKagawa et al. (1976) found a layer below $0^{\circ} \mathrm{C}$ at the depths beneath (about $6 \mathrm{~m}$ in depth) the melting snowpacks in a sub-alpine zone in the Hida Range, for several weeks at the begining of the melting season. This observation suggests that the conservation of the low temperature beneath the depth of snowcover would be the effect of the insulation by enormouse accumulation.

There are many sites at which the snow depth exceeds $30 \mathrm{~m}$ on Mt. Chokai, and the maximum depth of Kaigata Glacieret exceeded $45 \mathrm{~m}$. A cold ice layer below $0^{\circ} \mathrm{C}$ in 1975 lasted throughout the melting season possibly because of this deep snow cover. Consequently, it is probable that the melting-refreezing process occurs repeatedly during the melting season.
A third process should also be considered in which rapid transformation of snow into ice due to sintering at melting or near melting temperatures, as was observed in a laboratory experiment (WaKaнAмa, 1965). The major part of the remnant of snowpack on Mt. Chokai was apparently near the melting temperature in a surrounding far above $0^{\circ} \mathrm{C}$ during the most of the period from April to October.

At the site of Kaigata Glacieret, it is assumed that the above mentioned three processes or at least two of them (the first and third) probably may occur, but further confirmation will be necessary. The second process was less important for the transformation of snow into ice except very cold 1974/75 winter, because we have not observed the low ice temperature in the other surveys during the period from 1978 to 1981. The two-year-old layer of Kaigata Glacieret possibly developed into glacier ice after only one ablation (melting) season and an additional snowfall. This snow covered the two-year-old layer by a depth of some $30 \mathrm{~m}$ in the next winter.

Examinations on the nature of the accumulated materials were made by polarizing microscopic observation, and the materials were classified into glacier ice according to their optical and crystal properties as well as their density (Tsuchiy a, 1977).

\section{Interannual fluctuation and glacial flow of Kaigata Glacieret}

Figure 3 shows the interannual fluctuation of Kaigata Glacieret during the period from 1972-1981 by horizontal projection. The depth fluctuation of Kaigata Glacieret is considerably large in spite of the small size of the area because of the topography of this glacier's bed.

In 1972 and 1979 when the snow area reduced to a minimal size, the depth of snow in the central part was about $2 \mathrm{~m}$, while in 1974 when the widest extension of snow was observed, the depth was assumed to reach about $20 \mathrm{~m}$ (Figure 2-b). Consequently, the mass fluctuation is very large, and it is difficult to express interannual fluctuation in terms of the rise and fall of the equilibrium line. The entire area was covered by a snowcover in one year, but shrunk with the ablation of the one-year 


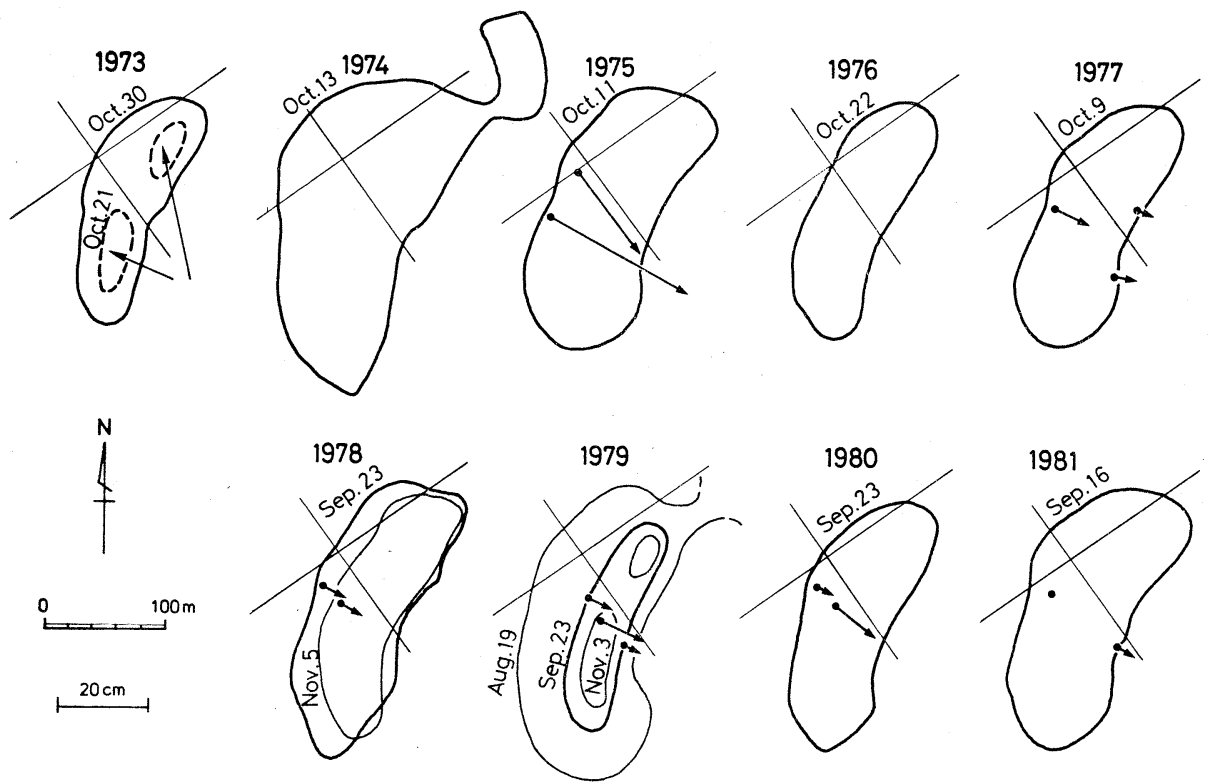

Figure 3. Year to year fluctuations of Kaigata Glacieret. (Thin arrows show flow amounts $(\mathrm{cm})$ and directions.)

Table 2. Interannual fluctuations of Kaigata Glacieret and climatological data at neighboring stations.

\begin{tabular}{|c|c|c|c|c|c|c|c|c|c|}
\hline & \multicolumn{4}{|c|}{$\begin{array}{l}\text { Mean temperature }\left({ }^{\circ} \mathrm{C}\right) \text { and } \\
\text { total precipitation }(\mathrm{mm}) \\
\text { from November to March }\end{array}$} & \multirow{2}{*}{$\begin{array}{l}\text { Trend of } \\
\text { mass } \\
\text { balance }\end{array}$} & \multirow{2}{*}{$\begin{array}{l}\text { Ares } \\
(\mathrm{S}: \mathrm{ha})\end{array}$} & \multirow{2}{*}{$\begin{array}{l}\text { Maximum } \\
\operatorname{depth}(\mathrm{D}: \mathrm{m})\end{array}$} & \multirow{2}{*}{$\begin{array}{l}\text { Volume } \\
\left(\mathrm{V}: \times 10^{4} \mathrm{~m}^{3}\right)\end{array}$} & \multirow{2}{*}{$\begin{array}{l}\text { Date and } \\
\text { measurement } \\
\text { technique }\end{array}$} \\
\hline & $\begin{array}{l}\text { Akita } \\
39^{\circ} 43^{\prime} 1 \\
140^{\circ} 06^{\prime}\end{array}$ & $\mathrm{N}$, $9 \mathrm{~m}$ & $\begin{array}{l}\text { Sakat: } \\
38^{\circ} 54^{\prime} \\
139^{\circ} 51\end{array}$ & $\begin{array}{l}\mathrm{a} \\
\mathrm{N}, \\
\mathrm{I}^{\prime} \mathrm{E},\end{array}$ & & & & & \\
\hline 1972 & $3.1^{\circ} \mathrm{C}$ & $660 \mathrm{~mm}$ & $4.4^{\circ} \mathrm{C}$ & $693 \mathrm{~mm}$ & - & 0.2 & 2 & 0.2 & Oct. 21 GP \\
\hline 1973 & 3.3 & 796 & 4.6 & 1046 & + & 1.2 & 7 & 4.2 & Oct. $30 \mathrm{AP}, \mathrm{GP}$ \\
\hline 1974 & 1.7 & 946 & 3.0 & 1085 & + & 3.6 & $15-20$ & 31.5 & Oct. 13 AP, TC \\
\hline 1975 & 1.5 & 517 & 2.7 & 563 & - & 2.0 & 10 & 10.0 & Oct. $11 \mathrm{~T}$ \\
\hline 1976 & 2.5 & 599 & 3.8 & 625 & - & 1.3 & 5 & 3.3 & Oct. 22 GP, AP \\
\hline 1977 & 1.5 & 527 & 2.6 & 702 & + & 1.7 & 10 & 8.5 & Oct. 9 GP \\
\hline 1978 & 2.5 & 692 & 3.9 & 826 & - & 1.2 & 6 & 3.6 & Nov. 5 GP \\
\hline 1979 & 3.5 & 584 & 4.7 & 843 & - & 0.3 & 2 & 0.3 & Nov. 3 GP \\
\hline 1980 & 2.8 & 639 & 4.1 & 904 & + & 1.6 & 8 & 6.4 & Sept. 23 GP \\
\hline 1981 & 2.6 & 510 & 3.7 & 805 & + & 2.1 & 12 & 12.6 & Sept. 16 GP, TC \\
\hline
\end{tabular}

snowpack and the two-year-old ice in another year. If an accumulation year represents the growth in size of a glacier and an ablation year represents the shrinkage, then, 1973, 1974, 1977,1980 and 1981 will be labelled as accumulation years, and 1972, 1975, 1976, 1978 and 1979 will be ablation years.
The major controling factor in the interannual fluctuations of Kaigata Glacieret are the interannual meteorological fluctuations which bring snowfall and snowdrift. Table 2 shows the mean air temperature and total precipitation in the winter for five months at the synoptic meteorological stations in Akita and Sakata. 
Table 3. Daily surface flow $(\mathrm{cm})$ and ablation depth $(\mathrm{cm})$.

\begin{tabular}{|c|c|c|c|c|c|c|c|c|c|c|c|c|c|c|}
\hline \multicolumn{2}{|c|}{ Year } & \multicolumn{3}{|c|}{1975} & \multirow{2}{*}{$\begin{array}{c}1977 \\
\text { Oct. } \\
9\end{array}$} & \multirow{2}{*}{ 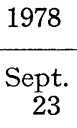 } & \multicolumn{6}{|c|}{1979} & \multirow{2}{*}{$\begin{array}{c}1980 \\
\text { Sept. } \\
23\end{array}$} & \multirow{2}{*}{ 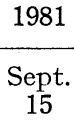 } \\
\hline Start & $\begin{array}{l}\text { Month } \\
\text { Date }\end{array}$ & $\underset{19}{\text { Aug. }}$ & $\underset{20}{\text { Aug. }}$ & $\begin{array}{c}\text { Oct. } \\
8\end{array}$ & & & $\underset{4}{\text { Aug. }}$ & $\begin{array}{c}\text { Aug. } \\
19\end{array}$ & $\begin{array}{c}\text { Aug. } \\
19\end{array}$ & Sept. & Sept. & $\begin{array}{c}\text { Sept. } \\
24\end{array}$ & & \\
\hline Elace & $\begin{array}{l}\text { Month } \\
\text { Date }\end{array}$ & $\begin{array}{c}\text { Aug. } \\
20\end{array}$ & $\begin{array}{c}\text { Oct. } \\
11\end{array}$ & $\begin{array}{c}\text { Oct. } \\
11\end{array}$ & $\begin{array}{c}\text { Oct. } \\
11\end{array}$ & $\begin{array}{c}\text { Sept. } \\
24\end{array}$ & $\underset{6}{\text { Aug. }}$ & $\underset{20}{\text { Aug. }}$ & $\begin{array}{c}\text { Sept. } \\
2\end{array}$ & $\begin{array}{c}\text { Sept. } \\
9\end{array}$ & $\begin{array}{c}\text { Sept. } \\
23\end{array}$ & $\begin{array}{c}\text { Sept. } \\
26\end{array}$ & $\begin{array}{c}\text { Sept. } \\
26\end{array}$ & $\begin{array}{c}\text { Sept. } \\
17\end{array}$ \\
\hline \multicolumn{2}{|c|}{ Upstream } & \multicolumn{3}{|c|}{$23-38$} & 8 & 8.7 & & 4.4 & 6.0 & 5.7 & & & 6.0 & 0.0 \\
\hline \multirow{2}{*}{\multicolumn{2}{|c|}{$\begin{array}{l}\text { Midstream } \\
\text { Downstream }\end{array}$}} & & & & & & & 5.3 & 7.2 & 4.3 & 7.0 & & 12.5 & \\
\hline & & 15 & & & & 5.6 & & 13.6 & & 7.3 & 8.2 & & & \\
\hline \multicolumn{2}{|l|}{ Snout } & & & 1 & $2-5$ & & & & & & & 1.7 & 0.5 & 1.0 \\
\hline \multicolumn{2}{|c|}{ Ablation } & & & & & & \multicolumn{6}{|c|}{ Aug. 19-Sept. 9} & & \\
\hline \multicolumn{2}{|l|}{ Depth } & & & 7 & 6 & & 31.7 & & & 23.6 & & 7.9 & 4.6 & 6.0 \\
\hline
\end{tabular}

Akita is located $70 \mathrm{~km}$ north and Sakata is located $25 \mathrm{~km}$ southwest of this glacier. Using the lapse rate of air temperature, we can estimate the meteorological environment of Kaigata Glacieret. The precipitation from November to March at the site of Kaigata Glacieret is considered generally to fall as snow, if $0.6^{\circ} \mathrm{C} / 100 \mathrm{~m}$ is applied to the temperature lapse rate. Accordingly, it is probable that the winter of $1973 / 74$ was cold with much snowfalls and Kaigata Glacieret developed rapidly, but that the winters of 1971/72 and 1978/79 were warm and with fewer snowfalls, causing this glacier to greatly diminish in size. However, the relation between cold and few snowfall winters and warm and much snowfall winters is not clear.

In accumulation years, there were several small snow patches at altitudes lower than Kaigata Glacieret. In ablation years, most of the patches disappeared. These phenomena were recorded several times in a year by several hundred photographs taken on the southern slope of Mt. Chokai (at a fixed point) during 1972-1981.

At altitudes higher than the site of Kaigata Glacieret, there is a wide area with no perennial snow patches in ablation years. But in accumulation years, temporal perennial snow patches appear there, and several of them develop into glacierets in accordance with the extension of Kaigata Glacieret. These glacierets and perennial snow patches diminish in size or disappear in ablation years but more slowly than those at lower altitudes.
Since 1977, glacial flows have been recorded every year. Representative cases of speed and direction of flow are shown by arrows in Figure 3, and all the measured values are listed in Table 3. The maximum flow during 19771981 was $13.6 \mathrm{~cm} /$ day and $23-38 \mathrm{~cm} /$ day in 1975.

These daily velocity values are obtained from the steel tape measurements of the length between the fixed points on the bed rock and the stake on the glacier during several days. In 1975, additional triangulations for two inverse pyramid shape stones on the glacier surface during fifty two days suggest larger values $(23-38 \mathrm{~cm} /$ day).

Some local differences in flow speed on the glacier can be seen in the 1979 survey. The flow is more rapid in the lower part than upstream but it reduces again at the snout. In the ablation years, the flow is more rapid than accumulation years.

The above phenomena may be explained as follows. In the accumulation years, the new snow accumulation overflows the bed rock which serves as a sliding surface as a result of the packaging effect on the small old ice bodies formed in the preceding year. Sliding surfaces of bed rocks are rather flat affording good condition for sliding and many scratched lines were recognized on it especially in 1975 and 1979. Namely, in a specified ablation year, a rather small but rather thick ice body flows more rapidly than that of the preceeding accumulation year. 


\section{A comparison of two small glac- iers in Japan and New Zealand}

There are ten or more small cirque glacires in the Front Range, Rocky Mountains, U.S.A. (Alford, 1973), but the air temperatures at these sites are about $10^{\circ} \mathrm{C}$ lower than the site of Kaigata Glacieret, and there are fewer snowfalls, although the latitude is about the same.

Whakapapanui Glacier in Mt. Ruapehu, North Island, New Zealand, has a lower temperature and less snowfall but in other respect is similar to Kaigata Glacieret. Table 4 shows a comparison of the two glaciers based on the data of several papers (Thompson and Kells, 1972; Tsuchiy A, 1977, 1978a, b).

Thompson and Kells report that, since 1940, the equilibrium line of the glacier has been located well above the summit of the mountain, and mass balance studies revealed a unique net gain in firn on the galcier in 1968-1969 for the first time in 20 years. The 1968-1969 firn disappeared in the following ablation season. Kaigata Glacieret has also shown repeatedly diminishing and extension following a rapid development in 1974 . These two glaciers share many features in common as small galciers formed far below the climatic snowline. That is, the prevailing wind in the snowfall season is westerly, and its leeward slope fronts on the low latitude and is bathed in sunshine. Many snowdrift accumulations are available and considerably large ablations frequently occur during the warm rainstorms.

The two glaciers differ in other important respects. Although Whakapapa Glacier is located just below the summit of Mt. Ruapehu, the original outlet diminished and separated into two "cut off" lobes, i.e. the Whakapapanui and Whakapapaiti Glaciers. Thus, the Whakapapanui Glacier became a climatically and dynamically "dead" ice for two decades until its temporary rebirth as a result of a unique net gain in firn over the glacier in 1968-1969 (Thompson and Kells, 1972). Mt. Chokai is about $500 \mathrm{~m}$ lower than Mt. Ruapehu. Although their meteorological environment is partly similar to that of Mt. Ruapehu, the formation of an outlet of glacier or ice cap glacier near the summit of Mt. Chokai would be almost impossible. Small perennial snow patches and glacierets or temporal glaciers are scattered only over the southern slope as can be seen from Figure 1.

However, there are several important com-

Table 4. Two small glaciers in Japan and New Zealand.

\begin{tabular}{|c|c|c|}
\hline Location & $\begin{array}{l}\text { Mt. Chokai }\left(2,237 \mathrm{~m}, 39^{\circ} 06^{\prime} \mathrm{N}, 140^{\circ} 03^{\prime} \mathrm{E}\right) \text {, } \\
\text { Japan }\end{array}$ & $\begin{array}{l}\text { Mt. Ruapehu }\left(2,752 \mathrm{~m}, 39^{\circ} 17^{\prime} \mathrm{S}, 175^{\circ} 33^{\prime}\right. \\
\text { E), New Zealand }\end{array}$ \\
\hline Glacier name & Kaigata (shell shape) & Whakapapanui \\
\hline Topography & Southern slope, active volcano & Northern slope, active volcano \\
\hline $\begin{array}{l}\text { Thickness, area, } \\
\text { altitude }\end{array}$ & $\begin{array}{l}\text { Mean: } 8 \mathrm{~m} \text { (max.: about } 20 \mathrm{~m}), 36,000 \mathrm{~m}^{2} \text {, } \\
\quad 1,350 \mathrm{~m}-1,450 \mathrm{~m} \text { (Oct. } 1974)\end{array}$ & $\begin{array}{l}\text { Mean: } 9 \mathrm{~m}, 37,000 \mathrm{~m}^{2}, 2,273 \mathrm{~m}-2,450 \mathrm{~m} \\
\quad \text { (May 1968) }\end{array}$ \\
\hline Source & Drifted snow & Drifted snow \\
\hline $\begin{array}{l}\text { Prevailing wind in } \\
\text { winter }\end{array}$ & Westerly or northwest & Westerly or southwest \\
\hline $\begin{array}{l}\text { Mean temperature } \\
\text { in ablation season }\end{array}$ & About $10^{\circ} \mathrm{C}$ (Apr. - Oct.) & About $4^{\circ} \mathrm{C}$ \\
\hline $\begin{array}{l}\text { Snow depth at the end } \\
\text { of winter }\end{array}$ & $\begin{array}{l}\text { More than } 45 \mathrm{~m} \text { (max.), at least more } \\
\text { than } 20 \mathrm{~m}\end{array}$ & \\
\hline Total annual ablation & Mean: $30 \mathrm{~m}$ & \\
\hline $\begin{array}{l}\text { Net accumulation } \\
\text { during the developed } \\
\text { year }\end{array}$ & $\begin{array}{l}\text { Mean: } 5 \mathrm{~m} \text {, max.: more than } 15 \mathrm{~m} \text { (Oct. } \\
\text { 1974) }\end{array}$ & Mean: $2.63 \mathrm{~m}, \max .: 5.00 \mathrm{~m}$ (May 1968) \\
\hline $\begin{array}{l}\text { Observed maximum } \\
\text { ablation rate }\end{array}$ & $\begin{array}{l}58.5 \mathrm{~cm}\left(0.60 \mathrm{~g} / \mathrm{cm}^{3}\right) / 40 \text { hours or } 210 \mathrm{~mm} \\
\text { water/day in warm }\left(16^{\circ} \mathrm{C}\right) \text { rainfall in } \\
1979\end{array}$ & $\begin{array}{l}76 \mathrm{~cm}\left(0.35 \mathrm{~g} / \mathrm{cm}^{3}\right) / 70 \text { hours or } 91 \mathrm{~mm} \\
\text { water/day in warm }\left(5^{\circ} \mathrm{C}\right) \text { rainfall in } \\
1968\end{array}$ \\
\hline References & $\begin{array}{l}\text { TSUCHIYA }(1977,1978 \mathrm{a}, \mathrm{b}) \text { and } 1976-1979 \\
\text { observation }\end{array}$ & Thompson and KeLLS (1972) \\
\hline
\end{tabular}


mon features between them. Their densities at the end of the snowfall season are very high, becoming almost that of glacier ice at the end of the first ablation season. Consequently, the rapid glacier development occurs from rapid densification into glacier ice after a transient extraordinary heavy snowfall or abnormally cool summer.

As shown in Table 4, the net accumulation of Kaigata Glacieret during the developed year is very larger than the case of Whakapapanui Glacier, and it is also similar to the observed maximum ablation rate. Accordingly, the interannual fluctuation of Kaigata Glacieret is considerably larger than that of Whakapapanui Glacier as a result of the unsteady mass balance originating from the variations in the amount of winter snowfall and the summer temperature, namely, a great variation in the extent of ablation.

\section{Further remarks on small scale glacial phenomena}

There is no climatic snowline at present in the Japanese mountains because of the high summer temperature. However, there are several perennial snow and ice patches in leeward niches or hollows. Thus, topographic snowlines are fragmentarily distributed and there is no perennial snow or ice patches at altitudes higher than the snowlines. Due to the temporal large amount of snowfall and snowdrifts exceeding the amount of annual ablation, very deep perennial snow patches are formed on the leeward niche sites at subalpine altitudes, in a warm temperature environment which is warm enough to allow for tree growth. Several such snow patches develop into very small but temporal glaciers by rapid densification. Kaigata Glacieret is an example of this.

The glacier size is very small because such niches containing a very deep snowdrift accumulation are also small. However, the glacier shows occasionally clear flows and related crevasses and other phenomena, and thus may be regarded as active. It almost diminishes completely during a period of

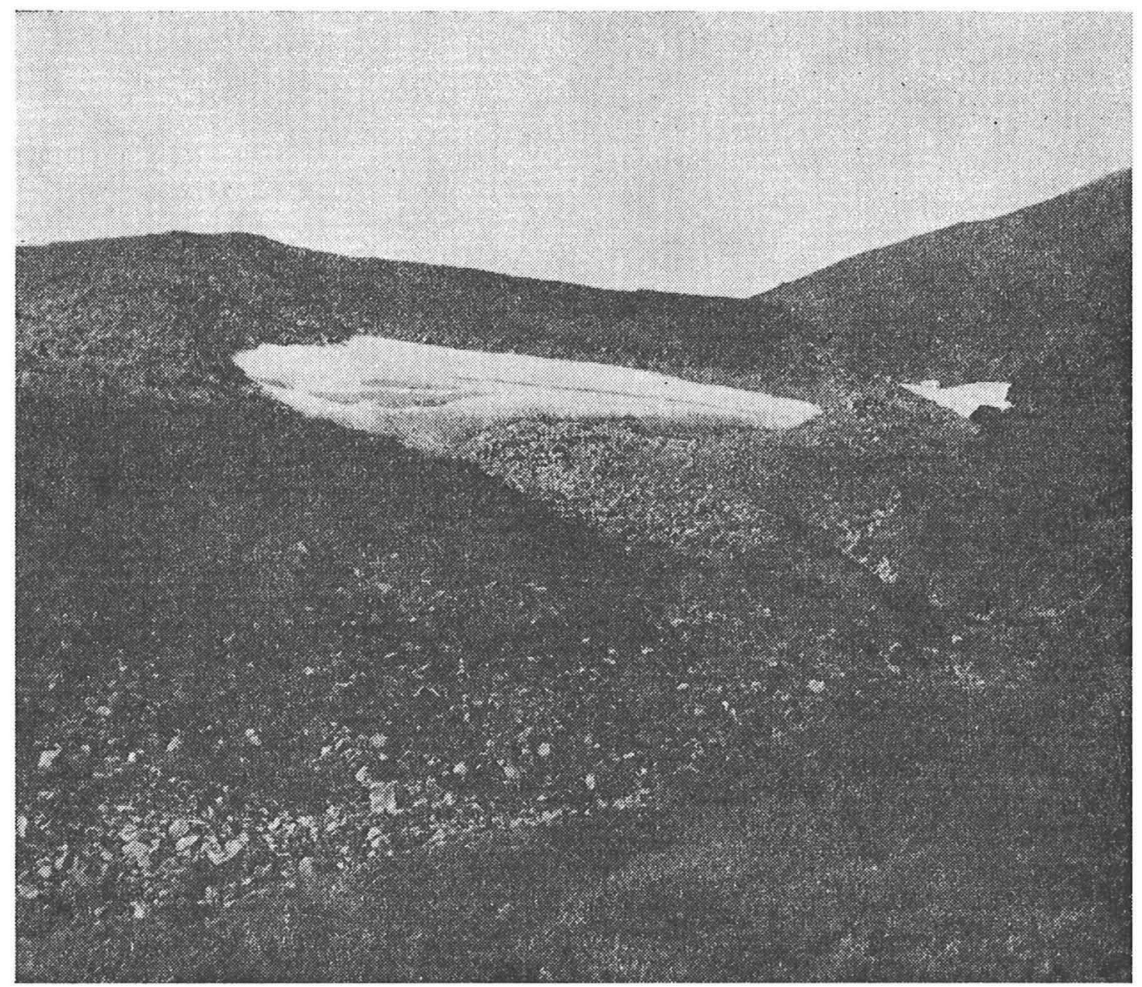

Figure 4. Kaigata Glacieret on September 22, 1980. 
several years but then rapidly develops into an active glacier for a few years. Such glaciers are present in the center area of snow patch vegetation with many alpine botanical species, in contrast to the landscape of a typical cirque glacier surrounded by rock cliffs with poor vegetations.

Figure 4 shows a photograph taken at a site about $600 \mathrm{~m}$ southeast of Kaigata Glacieret. Three transverse crevasses are formed on the lower part of this glacier. Rich vegetations and ice bodies coexist in this environment. This is a peculiar feature of a small glacier in a sub-alpine zone, and may be regarded as a new subject in the study of glaciology and alpine environment.

\section{Acknowledgments}

The author wishes to express his appreciation to Professor T. Oshima, Hosei University; Dr. T. Yamada, Hokkaido University; Mr. S. IkEDA, Matsuyama Rijinkan High School; and Mr. T. Iwozawa and Mr. T. ANDo for their comments and assistance in the field work.

(Received September 13, 1983) (Accepted April 28, 1984)

\section{References}

Alford, D.L. (1973): Cirque glaciers of the Colorado Front Range: mesoscale aspects of a glacier environment. Thesis, University of Colorado (Ann Arbor, MI., Univ. Microfilms, 1975), 198 p.

Fuкur, E. (ed.) (1977): The Climate of Japan. Elsevier, Amsterdam, $317 \mathrm{p}$.

Higuchi, K. (1979): Introductory remarks on the studies of perennial snow patches in Japan. Seppyo (Journal of Japanese Society of Snow and Ice), 41, 1-7. (in Japanese).
Müller, F., Caflisch, T. and Müller, G. (1977): Instructions for compilation and assemblage of data for a world glacier inventory. TTS, Zürich, $29 \mathrm{p}$.

Nakagawa, M., Kawata, K., Orabe, T., Shimizu, H. and Akitaya, E.(1976): Physical properties of the snow cover on Mount Tateyama in Central Honshu, Japan. Seppyo (Journal of Japanese Society of Snow and $I c e), 38,157-164$. (in Japanese).

Thompson, R.D. and Kells, B.R. (1972): Mass balance studies on the Whakapapanui glacier, New Zealand. IAHS-AISH Publication, 107, 383393.

Tsuchiya, I. (1974): Perennial snow covers, tiny glacierets and snow fields in Japan as indices of climatic fluctuations. Geophysical Magazine, 37, 147-161.

TSUCHIYA, I. (1976): Airborne photogrammetrical estimations of extraordinary snow depths in Mounts Iide, Gassan and Chokai and a preliminary report on the birth of a small glacier. Seppyo (Journal of Japanese Society of Snow and Ice), 38, 178-187. (in Japanese).

Tsuchiya, I. $(1977,1978 \mathrm{a}, 1978 \mathrm{~b})$ : The glacioclimatological study on the Kaigata Glacieret, Mt. Chokai (1), (2), (3). Seppyo (Journal of Japanese Society of Snow and Ice), 39, 65-76; 40, 1-9; 40, 10-21. (in Japanese).

UNESCO/IASH (1970): Perennial ice and snow masses. Technical Papers in Hydrology, 1, 59 p.

WaKaHAMA, G. (1965): Metamorphisms of wet snow. Low Temperature Science, Series $A$, Hokkaido University, 23, 51-66, +4 photos. (in Japanese).

Wakahama, G. et al. (1969): Studies of firn on Mt. Daisetsu in summer (IV). Low Temperature Science, Series A, 27, 181-194, +2 plates. (in Japanese).

Wakahama, G. and Yamada, T. (1979): Survey of the perennial snow patches in the Daisetsu Mountains, Hokkaido. Seppyo (Journal of Japanese Society of Snow and Ice), 41, 11-18. (in Japanese).

\section{鳥海山における非常に小さな水河の 1972年-1981年 の推移}

土屋篇*

世界水河台帳作成計画のための IASH（国際水文科学 協議会）の分類 (UNESCO/IASH, 1970) と MÜLLER 注 か（1977）によるその改訂版を参照して，筆者はさきに
なだれを含まずに，異常に大量の降雪と吹さだまり雪と によって形成される亜高山带のニッチ水河を, 山岳水河 の一型式として提案し,“鳥海山型水河”と名付けた（土

\footnotetext{
$*$ 于305 茨城県筑波郡谷田部町26 国立公害研究所
} 
屋, $1978 \mathrm{a}, 1978 \mathrm{~b}) 。 1972$ 年一1981年の間, この型の氷 河のひとつで “貝形小水河”と命名したものについて, 每年野外調查を実施し，その特色を解明した。

貝形小水河は，いわゆる気候的雪線よりも $2,000 \mathrm{~m}$ 泀 ど低い, 海抜約 $1,400 \mathrm{~m}$ 高度に形成されるが, 拡大期に は約 $0.04 \mathrm{~km}^{2}$ の大きさになり, また $2 \sim 3$ 年のらちに ごく小さな氷体縮小することがある。この氷河の存在 場所の積雪深算定值の最大は $45 \mathrm{~m}$ 以上であった。消耗 量が大さく, 暖かい大雨の際には毎時 $1.4 \mathrm{~cm}$ の厚さ減 少が観測された。氷河氷の形成は非常に早く, この水河 上の残雪の密度は, 最初の消耗季節の終り頃までのわず かな期間に，ほとんど氷河氷の段階にまで増加する。
貝形小水河の流動現象は一定でなく，蓄積年後の消耗 年である 1975 年や 1979 年の場合にはかなり早い流動を 示した。日本の他の地域に見られるいくつかの多年性残 雪（氷体を内在する）では, さらに小規模で貝形小水河 と同様のものもあるが，明白な流動現象はまだ報告され ていない。

ニュージーランドの Whakapapanui 氷河は, 貝形小水 河とほぼ同じ規模の小さな水河であるが，両者の比較に より, 気候的雪線のはるか下方で形成され，降雪季節の 卓越風が偏西風であり, 風下斜面に存在して低緯度に面 し，主涵養源は吹きだまり雪であって，氷河質量の年々 変動が大きいなどの共通の性質のあることがわかった。 